\title{
HUBUNGAN FAKTOR SOSIAL EKONOMI, HIGIENE SANITASI LINGKUNGAN, TINGKAT KONSUMSI, DAN KEJADIAN INFEKSI DENGAN STATUS GIZI ANAK USIA 2-5 TAHUN DI DESA TUBLOPO TAHUN 2014
}

\author{
Hetty Gustina Simamora \\ Staff Pengajar STIKes Santa Elisabeth Medan
}

\begin{abstract}
Background: The existence of multidimensional crisis has menurnkan nutritional status of society. one of the community groups that are susceptible to the decline of nutritional status of children aged 2-5 years, because at this age the child was not getting milk while the food consumed has not been sufficient to meet the growing nutritional needs. Nutritional status is indirectly related to socioeconomic factors, sanitation hygiene, consumption level and the incidence of infection.

Method: This research is an observational study with survey method and desaim cross sectional. Samples are children aged 2-5 Years residing in the village Tublopo. The sample size is 76 children taken proportionally. Respondents were mothers of the sample. The statistical test used is Rank Spearman and Chi-Square.

Result : Respondents came from low socio economic groups with low knowledge of nutrition, 93.4\% energy consumption level, sample including deficit and protein consumption rate of $35.5 \%$ sample including deficit. In the last three months and at the time of the study, $63.2 \%$ of the samples had upper respiratory tract infection (ISPA) and 1.3\% of samples suffering from diarrhea, 39.6\% of the samples had nutritional status of ARI occurrence related to $Z B B / U$ score in child age 2-5 years. The level of education of the mother is related to the level of energy and protein consumption.

Conclusion: To anticipate the improvement of malnutrition status, it is suggested to the community, especially the mothers who have not fulfilled their obligation to learn 9 years to participate in the C package program and for TTU District Health Office to provide interesting counseling to improve mother's knowledge about giiz and the importance of the prevention of ARI
\end{abstract}

Keywords: Nutritional Status, Sanitation Hygiene, Socio-Economic, Consumption Level of Funds Children 2-5 Years 


\section{PENDAHULUAN}

Status gizi memiliki pengaruh yang sangat besar dalam mewujudkan sumber adaya manusia yang berkualitas dimana yang akan datang. Status gizi berhubungan dengan kecerdasan anak. Pembentukan kecerdasan pada masa usia dini tergantung pada asupan zat gizi yang diterima. Semakin rendah asupan zat gizi yang diterima, semakin rendah pula status gizi dan kesehatan anak. Gizi kurang atau buruk pada masa bayi dan anak-anak terutama pada umur kurang dari 5 tahun dapat mengakibatkan terganggunya pertumbuhan jasmani dan kecerdasan anak. Pertumbuhan sel otak berlangsung sangat cepat dan akan berhenti atau mencapai sempurna pada usia 4-5 tahun. Perkembangan otak yang cepat hanya dapat dicapai bila anak berstatus gizi baik (Depkes RI, 2002:Soendjojo dkk 2000)

Cara menilai statu gizi dapat dilakukan dengan pengukuran antropemetrik, klinik, biokimia, dan biofisik. Pengukuran antropemetrik, klinik, biokimia, dan biofisik. Pengukuran antropemetrik dapat dilakukan dengan beberapa macam pengukuran yaitu pengukuran berat badan, tinggi badan, lingkar lengan atas, dan sebagainya. Dari beberapa pengukuran tersebut, pengukuran berat badan (BB) sesuai umur (U) merupakan salah satu pengukuran antropometrik yang sering dilakukan dalam survei gizi (Dep.Kes Ri, 2002:Soekirman 2000)

Berdasarkan indicator $\mathrm{BB} / \mathrm{U}$, status gizi dibagi menjadi 4 yaitu status gizi lebih, status gizi baik, status gizi kurrang dan status gizi buruk. Status gizi lebih, status gizi kurang dan status gizi buruk sama-sama mempunyai risiko yang tidak baik bagi kesehatan. Status gizi lebih dapat menyebabkan meningkatnya penyakit degeneratif, seperti jantung koroner, diabetes mellitus, hipertensi dan penyakit hati. Status gizi yang rendah pada balita dapat menyebabkan angka kematian yang tinggi pada bayi dan anak-anak, terganggunya pertumbuhan badan, menurunnya daya kerja, gangguan perkembanagan mental dan kecerdasan serta terdapatnya berbagai jenis penyakit tertentu (Almatsier, 2001)

Menurut Almatsier (2001), masalah gizi lebih disebabkan oleh kemajuan ekonomi pada lapisan tertentu disertai kurangnya pengetahuan tentang gizi dan kesehatan. Menurut Arnelia dan Sri Muljati (1991), adanya penurunan status gizi disebabkan karena kurangnya jumlah makanan yang dikonsumsi baik secra kuantitas maupun kualitas. Kuantitas dan kualitas pangan yang dikonsumsi dipengaruhi oleh tingkat pendidikan ibu, tingkat pengetahuan ibu tentang gizi, ketersediaan pangan dikeluarga dan tingkat pendapatan keluarga.

Telah lama diketahui hubungan yang sinergis antara malnutrisi dan oinfeksi. Infeksi derajat apapun dapat memperburuk keadaan gizi (Pudjadi, 2000). Penyakit infeksi yang mempengaruhi terjadinya gizi buruk adalah Infeksi Saluran Pernapasan Bagian Atas (ISPA) dan diare. Menurut Ezzel dan gorgon penyakit paru-paru kronis juga dapat mempengaruhi terjadinya gizi buruk. Penyakit infeksi akan menyebabkan gangguang gizi melalui beberapa cara yaitu menghilangkan bahan makanan melalui muntah-muntah dan diare. Selain itu penyakitt infeksi dapat menurunkan nafsu makan. Kejadian infeksi terkait dengan kondisi hygiene sanitasi lingkungan yang buruk (Pudjadi, 2000).

Analisis data Susenas 1999 menunjukkan bahwa prevalensi gizi lebih besar 4,48\% dan prevelansi gizi buruknya sebesar 9,5\%. Pada tahun 1999 diperkirakan 1,7 juta anak balita mengalami gizi buruk. Dari jumlah tersebut 170.000 anak berada dalam gizi buruk tingkat berat yang disebut kwashiorkor dan marasmus (Almatsier, 2001:Jahari dkk, 2000).

Dari sini dapat dilihat bahwa prevelensi gizi buruk lebih besar dari pada prevalensi gizi lebih. Prevelansi gizi buruk mengalami peningkatan sejak terjadinya 
krisis ekonomi tahun 1997. Krisis tersebut telah menyebabkan meningkatnya jumlah keluarga miskin. Akibatnya, daya beli masyarakat melemah dan konsumsi pangan menurun (Tabor, dkk, 2000 : latief, dkk, 2000). Penelitian yang dilakukan oleh Laksmi Widajanti, dkk pada tahun 1999 menunjukka bahwa ada penurunan konsumsi energi, protein dan zat besi pada anak SD saat terjadinya krisis moneter.

Angka gizi buruk di NTT termasuk tinggi dibandingkan denga propinsi lainnya. Dari data kasus gizi buruk berdasarkan laporan petugas gizi kabupaten TTU dari Januari - Desember 2013 ditemukan sebanyak 2.309 kasus gizi bruk dengan rasio gizi buruk 9,14 per 1000 balita. Hal ini menunjukkan bahwa setiap 1000 baliata, maka 9 diantaranya mengalami gizi buruk. Oleh karena itu upaya untuk meningkatkan status gizi merupakan hal penting untuk dilakukan.

Berdasarkan uraian tersebut, penulis tertarik untuk meneliti lebih jauh mengenai hubungan faktor social ekonomi, sanitasi lingkungan, tingkat konsusmi, dan kejadian infeksi dengan status gizi anak yang telah disapihpada usia 2-5 tahun. Menurut Arnelia dan Sri Muljati (1991), pada usia ini mulai terjadi pergeseran status gizi dari gizi sedang ke gizi kurang. Hal ini diduga karena anak sudah tidak mendapatkan ASI, sedangkan makanan yang dikonsumsi belum memenuhi kebuthuna gizi yang semakin meningkat seiring dengan pertambahan umur.

Lokasi penelitian dipilih di desa Tublopo dengan pertimbangan prevelensi gizi buruk pada anak usia balita cukup tinggi. Desa Tublopo merupakan salah satu desa di kabupaten Bikomi Selatan dengan kasus gizi buruk tinggi yaitu sebanayak 72 kasus dengan rasio gizi buruk balita adalah 10,94/1000. Hal ini menunjukkan bahwa setiap 1000 balita terdapat 10 balita yang mengalami gizi buruk. Angka ini lebih tinggi bila dibandingkan dengan rasio gizi buruk Kecamtan Bikomi Selatan yaitu $9,14 / 1000$.

\section{METODE PENELITIAN}

Metode penelitian yang digunakan adalah survei dengan desain cross sectional yaitu suatu penelitian dimana pengumpulan data variabel bebas dan terikatnya dilakukan secara bersama-sama atau sekaligus. Penelitian ini dilakukan di desa Tublopo dan penelitian ini di laksanakan. pada bulan Januari - Februari 2014. Populasi dalam penelitian inin adalah semua anak usia 2- 5 tahun yang bertempat tinggal di desa Tublopo. Sampel pada penelitian ini adalah anak usia 2-5 tahun. Sedangkan responden adalah ibu dari anak usia 2-5 tahun. Besar sampel minimal pada penelitian ini dihitung berdasarkan rumu : (Lameshow Stanley, dkk, 1997).

\section{Pengelohan Data}

Setelah data dikumpulkan, dilakukan pengolahan data dengan tahaptahap sebagi berikut (Budiarto, 2002) :

1. Editing

Editing merupakan langkah untuk meneliti kelengkapan data yang diperoleh melalui wawancara. Editing dilakukan pada setiap daftar pertanyaan yang sudah diisi.

2. Coding

Adalah usaha untuk mengklasifikasikan jawaban yang ada menurut jenisnya. Dilakukan dengan member tanda pada masing-masing jawaban dengan kode burupa angka.

3. Tabulasi

Adalah kegiatan memasukkan datadata hasil penelitian ke dalam tabel berdasarkan variabel yang diteliti.

4. Entry Data

Adalah memasukkan data yang telah ditabulasi ke dalam kompuuter program SPSS for windows release 11,5 kemudian dilanjutkan analisis dat (Santoso, S, 2002). 
Metode Analisis Data

a) Analisa Deskriptif

Analisa deskriptif dibuat dengan menggunakan tabel-tabel untuk menggambarkan tingkat pendidikan ibu, tingkat pendapatan per kapita, tingkat pengetahuan ibu tentang gizi, jumlah anggota keluarga, kejadian ISPA dan diare, hygiene sanitasi lingkungan, tingkat konsumsi energy, tingkat konsusmsi protein, dan status gizi anak usia 2-5 tahun di Desa Tublopo Tahun 2014.

b) Analisa Inferensial

Sebelum menggunakan uji statistik, terlebih dahulu dilakukan uji kosmogorof Smirnoff untuk mengetahui kenormalan distribusi data variabel peenlitian. Dari hasil uji normalitas data tersebut maka uji statistik yang digunakan untuk menguji hubungan variabel bebas dengan variabel antara dengan variabel terikat adalah Rank Spearmen dan Chi-Square (Sugiyono, 1999)

\section{HASIL PENELITIAN}

\section{Karakteristik Ibu}

\section{Tingkat Pendidikan Ibu}

Dalam penelitian ini, tingkat pengetahuan ibu terendah 1 tahun, teringgi 13 tahun dan rata-rata 6,5 tahun dengan standar devisiasi 6,5 tahun. Sebagian besar responden tingkat pendidikannya kurang dari 9 tahun yaitu sebanyak $92 \%$ dan yang lebih dari 9 tahun ada $8 \%$.

Hasil penelitian ini menunjukkan bahwa pendidikan responden rendah karena belum mencapai batas minimal pendidikan dara yang diwajibkan pemerintah yaitu sampai 9 tahun (Sisdiknas, 2002)

Tabel 1. Distribusi Responden Berdasarkan Tingkat Pendidikan Ibu

\begin{tabular}{ccc}
\hline $\begin{array}{c}\text { Tingkat } \\
\text { Pendidikan } \\
\text { Ibu }\end{array}$ & $\begin{array}{c}\text { Jumlah } \\
\text { (orang) }\end{array}$ & $\begin{array}{c}\text { Persentase } \\
(\%)\end{array}$ \\
\hline$<9$ tahun & 70 & 92,0 \\
$\geq 9$ tahun & 6 & 8,0 \\
\hline Jumlah & $\mathbf{7 6}$ & $\mathbf{1 0 0 , 0}$ \\
\hline
\end{tabular}

\section{Tingkat Pendapatan Per Kapita}

Tingkat pendapatan per kapita terendah Rp. 25.000,00 tertinggi $\mathrm{Rp}$ 200.000,00 dan rata-rata $\mathrm{Rp} 78.789,00$, dengan standar devisiasi Rp. 32.644,00. Sebagian besar responden tingkat pendapatan per kapitanya lebih besar dari 72.780,00/kapita/bulan yaitu sebanyak $57,9 \%$. Berdasarkan batas kemiskinan dari BPS yaitu Rp 72.780,00/kapita/bulan, sebagian besar responden tingkat pendapatannya diatas garis kemiskinan.

Tabel 2 Distribusi Responden Berdasarkan Tingkat Pendapatan Per Kapita

\begin{tabular}{ccc}
\hline $\begin{array}{c}\text { Tingkat } \\
\text { pendapatan } \\
\text { Perkapita }\end{array}$ & $\begin{array}{c}\text { Jumlah } \\
\text { (orang) }\end{array}$ & $\begin{array}{c}\text { Persentase } \\
(\mathbf{\%})\end{array}$ \\
\hline$\leq \mathrm{Rp} \mathrm{72.780,00}$ & 32 & 42,1 \\
$>\mathrm{Rp} \mathrm{72.780,00}$ & 44 & 57,9 \\
\hline Jumlah & $\mathbf{7 6}$ & $\mathbf{1 0 0 , 0}$ \\
\hline
\end{tabular}

\section{Tingkat Pengetahuan Ibu Tentang Gizi}

Dalam penelitian ini, tingkat pengetahuan ibu tentang gizi terendah 5, tertinggi 11, dan rata-rata 9,2 dengan standar devisiasi 1,6 sebanyak 51,3\% responden tingkat pengetahuan gizinya termasuk kategori kurang.

Menurut Winarto (1990), pentingnya pengetahuan tentang gizi di dasarkan pada tiga kenyataan. Pertama, status gizi yang cukup merupakan sesuatu yang penting bagi kesehatan. Kedua, seseorang akan cukup gizi jika makanan yang dimakan mampu menyediakan zat gizi yang diperlukan untuk pertumbuhan yang optimal, pemeliharaan, dan energy. Ketiga, ilmu gizi memberikan fakta-fakta yang perlu sehingga penduduk dapat belajar menggunakan pangan dengan baik bagi kesehatan. 
Tabel 3 Distribusi Responden Berdasarkan Tingkat Pengetahuan Ibu Tentang Gizi

\begin{tabular}{lll}
\hline $\begin{array}{c}\text { Tingkat } \\
\text { Pengetahuan } \\
\text { Ibu Tentang } \\
\text { Gizi }\end{array}$ & $\begin{array}{c}\text { Jumlah } \\
\text { (Orang) }\end{array}$ & $\begin{array}{c}\text { Persentase } \\
(\boldsymbol{\%})\end{array}$ \\
\hline Baik $(>9)$ & 37 & 48,7 \\
Kurang $(\leq 9)$ & 39 & 51,3 \\
\hline Jumlah & $\mathbf{7 6}$ & $\mathbf{1 0 0 , 0}$ \\
\hline
\end{tabular}

\section{Jumlah Anggota Keluarga}

Dalam penelitian ini, jumlah anggota keluarga responden terendah 3 orang, tertinggi 12 orang, dan rata-rata 5 orang dengan standar devisiasi 1,6. Sebanyak 76,3\% responden jumlah anggota keluarganya termasuk sedikit yaitu kurang dari 6 orang. Banyak sedikitnya anggota keluarga berhubungan dengan distribusi makanan dalam suatu keluarga. Hasil penelitian Dini Latief, dkk (2000) menunjukkan bahwa selama terjadi krisis moneter, distribusi pangan yang dikonsumsi semakin memberuk pada rumah tangga yang mempunyai anggota yang cukup besar.

Tabel 4 Distribusi Responden Berdasarkan Jumlah Anggota Keluarga

\begin{tabular}{ccc}
\hline $\begin{array}{c}\text { Jumlah } \\
\text { Anggota } \\
\text { Keluarga }\end{array}$ & $\begin{array}{c}\text { Jumlah } \\
\text { (orang) }\end{array}$ & $\begin{array}{c}\text { Persentase } \\
(\mathbf{\%})\end{array}$ \\
\hline $\begin{array}{c}\text { Sedikit ( }<6 \\
\text { orang) }\end{array}$ & 58 & 76,3 \\
$\begin{array}{c}\text { Banyak ( } \geq 6 \\
\text { orang) }\end{array}$ & 18 & 23,7 \\
\hline Jumlah & $\mathbf{7 6}$ & $\mathbf{1 0 0 , 0}$ \\
\hline
\end{tabular}

\section{Tingkat Higiene Sanitasi Lingkungan}

Pada penelitian ini, skor hygiene sanitasi lingkungan responden terendah 10, tertinggi 23 dan rata-rata 17 dengan standar devisiasi 17,12 sebanyak $52,6 \%$ responden tingkat hygiene sanitasi lingkungannya termasuk dalam kategori cukup. Sanitasi lingkungan yang dinilai dalam penelitian ini meliputi ketersediaan air bersih, ketersediaan jamban, jneis lantai rumah serta kebersihan peralatan makan pada setiap keluarga.
Tabel 5 Distribusi Responden Berdasarkan Tingkat Higiene Sanitasi Lingkungan

\begin{tabular}{ccc}
\hline $\begin{array}{c}\text { Tingkat Higiene } \\
\text { Sanitasi } \\
\text { Lingkungan }\end{array}$ & $\begin{array}{c}\text { Jumlah } \\
\text { (orang) }\end{array}$ & $\begin{array}{c}\text { Persentase } \\
(\mathbf{\%})\end{array}$ \\
\hline Baik ( 20-24) & 20 & 26,3 \\
Cukup 15-19) & 40 & 52,1 \\
Kurang (10-14) & 16 & 21,1 \\
Jumlah & $\mathbf{7 6}$ & $\mathbf{1 0 0 , 0}$ \\
\hline
\end{tabular}

\section{Karakteristik Sampel}

\section{Tingkat Konsumsi Energi}

Pada penelitian ini, tingkat konsumsi energi sampel terendah 9\%, tertinggi $100 \%$, rata-rata $42,72 \%$ (deficit) dengan standar devisiasi $17,9 \%$. Sebagian besar sampel mengalami defisit yaitu sebesar 93,4\%. Angka ini lebih tinggi dari angka prevelansi rumah tangga di pedasaan pada tahun 1998 yang mengalami deficit energy yaitu sebesar $47,5 \%$.

Tabel 6. Distribusi Sampel Berdasarkan Tingkat Konsumsi Energi

\begin{tabular}{ccc}
\hline $\begin{array}{c}\text { Tingkat } \\
\text { Konsumsi } \\
\text { Energi }\end{array}$ & $\begin{array}{c}\text { Jumlah } \\
\text { (orang) }\end{array}$ & $\begin{array}{c}\text { Persentase } \\
(\%)\end{array}$ \\
\hline$\geq 100 \%$ (baik) & 1 & 1,3 \\
$\begin{array}{c}80-99 \% \\
\text { (sedang) }\end{array}$ & 1 & 1,3 \\
$70-80 \%$ & 3 & 3,9 \\
$\begin{array}{c}\text { (kurang) } \\
<70 \%\end{array}$ & 71 & 93,4 \\
(deficit) & & $\mathbf{1 0 0 , 0}$ \\
Jumlah & $\mathbf{7 6}$ & \\
\hline
\end{tabular}

\section{Tingkat Konsumsi Protein}

Pada penelitian ini, tingkat konsumsi protein sampel terendah 18,0\% dari Angka Kecukupan Gizi (AKG) yang dianjurkan, tertinggi 18,7\% AKG, dan rata-rata 82,21\% AKG standar devisiasi $33,96 \%$. Ini artinya rata-rata tingkat konsumsi protein sampel termasuk kategori sedang. Sebanyak 35,5\% sampel mengalami defisit, tetapi ada $25 \%$ sampel tingkat konsumsi protein dengan baik sesuai dengan Angka Kecukupan Gizi 
yang dianjurkan. Angka deficit protein pada penelitian ini lebih tinggi dari angka prevalensi rumah tangga yang mengalami defisit protein di pedesaan pada tahun 1998 yaitu sebesar 26,7\%.

Tabel 7. Distribusi Sampel Berdasarkan Tingkat Konsumsi Protein

\begin{tabular}{ccc}
\hline $\begin{array}{c}\text { Tingkat } \\
\text { Konsumsi } \\
\text { Energi }\end{array}$ & $\begin{array}{c}\text { Jumlah } \\
\text { (orang) }\end{array}$ & $\begin{array}{c}\text { Persentase } \\
(\%)\end{array}$ \\
\hline$\geq 100 \%$ (baik) & 19 & 25 \\
$80-99 \%$ & 20 & 26,3 \\
(sedang) & & \\
$70-80 \%$ & 10 & 13,2 \\
(kurang) & & \\
$<70 \%$ (defisit) & 27 & 35,5 \\
Jumlah & $\mathbf{7 6}$ & $\mathbf{1 0 0 , 0}$ \\
\hline
\end{tabular}

\section{Infeksi Saluran Pernapasan Bagian} Atas (ISPA)

Pada penelitian ini, dalam tiga bulan terakhir dan saat pengambilan data sebagian besar sampel yaitu sebanyak 63,2\% pernah mengalami Infeksi Saluran Pernapasan Bagian Atas (ISPA).

Tabel 8. Distribusi Sampel Berdasarkan mengalami Infeksi Saluran Pernapasan Bagian Atas (ISPA).

\begin{tabular}{ccc}
\hline ISPA & $\begin{array}{c}\text { Jumlah } \\
\text { (orang) }\end{array}$ & $\begin{array}{c}\text { Persentase } \\
(\boldsymbol{\%})\end{array}$ \\
\hline Ya & 48 & 63,2 \\
Tidak & 28 & 36,8 \\
\hline Jumlah & $\mathbf{7 6}$ & $\mathbf{1 0 0 , 0}$ \\
\hline
\end{tabular}

\section{Diare}

Pada penelitian ini, dalam tiga bulan terakhir dan saat pengambilan data hanya $1,3 \%$ sampel yang pernah mengalami diare.

Tabel 9 Distribusi Sampel Berdasarkan Diare

\begin{tabular}{ccc}
\hline ISPA & $\begin{array}{c}\text { Jumlah } \\
\text { (orang) }\end{array}$ & $\begin{array}{c}\text { Persentase } \\
(\boldsymbol{\%})\end{array}$ \\
\hline Ya & 48 & 63,2 \\
Tidak & 28 & 36,8 \\
\hline Jumlah & $\mathbf{7 6}$ & $\mathbf{1 0 0 , 0}$ \\
\hline
\end{tabular}

\section{Status Gizi}

Pada penelitian ini skor $\mathrm{Z}$ indeks $\mathrm{BB} / \mathrm{U}$ sampel terendah $-3,5$, tertinggi 1,9 dan rata-rata 1,74 (status gizi baik) dengan standar deviasi 1,79. Setelah dikelompokkan, sampel yang mempunyai status gizi buruk dan status gizi baik persentasenya sama yaitu masing-masing $39,6 \%$. Angka gizi buruk pada penelitian ini lebih tinggi dari angka gizi buurk hasil analisis data Susenas Tahun 2013 untuk kelompok usia 6-23 bulan. Analisis data Susenas tahun 2013 menunjukkan bahwa angka gizi buruk untuk kelompok usia 623 bulan sebesar $10,2 \%$.

Tabel 10 Status Gizi Berdasarkan Skor $\mathrm{Z}$ indeks BB/U

\begin{tabular}{ccc}
\hline Status Gizi & $\begin{array}{c}\text { Jumlah } \\
\text { (orang) }\end{array}$ & $\begin{array}{c}\text { Persentase } \\
(\boldsymbol{\%})\end{array}$ \\
\hline Baik & 30 & 39,6 \\
Kurang & 16 & 20,8 \\
Buruk & 30 & 39,6 \\
Jumlah & $\mathbf{7 6}$ & $\mathbf{1 0 0 , 0}$ \\
\hline
\end{tabular}

1. Hubungan Tingkat Pendidikan Ibu Dengan Tingkat Konsumsi Energi dan Protein

Uji statistik Rank Spearman menunjukkan ada hubungan tingkat pendidikan ibu dengan tingkat konsumsi energy $(r=0,331$ dan $p=0,0003)$ dan tingkat konsumsi protein ( $\mathrm{r}=0,383$ dan $\mathrm{p}$ $=0,0001$ ). Hal ini berarti bahwa semakin tinggi tingkat pendidikan ibu semakin tinggi tingkat konsumsi energy dan protein anaknya.

2. Hubungan Tingkat Pendapatan Perkapita Dengan Tingkat Konsumsi Energi dan Protein

Uji statistik Rank Spearman menunjukkan tidak ada hubungan tingkat pendapatan per kapita dengan tingkat konsumsi energi $(r=0,100$ dan $p=0,389)$ dan protein $(r=0,133$ dan $\mathrm{p}=0,251)$. Hal ini berarti tingkat konsumsi energy dan protein anatara anak dari keluarga miskin dengan anak yang berasal dari keluarga yang tidak miskin hamper sama. 
3. Hubungan Tingkat Pengetahuan Ibu Tentang Gizi Dengan Tingkat Konsumsi Energi dan Protein

Hasil Uji statistik Rank Spearman menunjukkan ada hubungan tingkat pengetahuan gizi ibu dengan tingkat konsumsi protein $(r=0,253$ dan $p=0,027)$. Hal ini menunjukkan bahwa pengetahuan ibu tentang gizi mempunyai peranan dalam meningkatkan konsumsi protein.

\section{Hubungan Jumlah Anggota Keluarga Dengan Tingkat Konsumsi Energi dan Protein \\ Hasil Uji statistik Rank} Spearman menunjukkan ada hubungan tingkat pengetahuan gizi ibu dengan tingkat konsumsi energi ( $\mathrm{r}=0,029$ dan $\mathrm{p}$ $=0,804)$ dan protein $(r=0,132$ dan $p$ $=0,256$ ). Dalam penelitian ini, jumlah anggota keluarga responden rata-rata 5 orang.

\section{Hubungan Tingkat Konsumsi Energi dan Protein Dengan Status Gizi}

Hasil Uji statistik Rank Spearman menunjukkan bahwa ada hubungan konsumsi energy dengan status gizi anak usia 2-5 tahun ( $\mathrm{r}=0,328$ dan $\mathrm{p}=0,004)$ demikian juga tingkat konsumsi protein dengan status gizi $(r=0,348$ dan $p=0,002)$. Hal ini berarti semakin tinggi tingkat konsumsi energi dan protein semakin baik status gizinya.

\section{Hubungan Tingkat Higiene Sanitasi Lingkungan Dengan ISPA}

Hasil Uji statistik Chi-Square menunjukkan bahwa tidak ada hubungan tingkat hygiene sanitasi lingkungan dengan terjadinya ISPA pada anak usia 2-5 tahun $\left(x^{2}=0,412\right.$ dan $\left.p=0,814\right)$. Hal ini berarti bahwa infeksi ISPA dapat terjadi pada tingkat hygiene sanitasi lingkungan baik, cukup, atau kurang.

\section{Hubungan Tingkat Higiene Sanitasi Lingkungan Dengan Diare}

Hasil Uji statistik Chi-Square menunjukkan bahwa tidak ada hubungan tingkat hygiene sanitasi lingkungan dengan terjadinya diare pada anak usia 2-5 tahun $\left(x^{2}=1,619\right.$ dan $\left.p=0,445\right)$. Hal ini berarti bahwa penyakit diare dapat terjadi pada tingkat hygiene sanitasi lingkungan baik, cukup atau kurang.

\section{Hubungan ISPA dengan Status Gizi}

Hasil Uji statistik Chi-Square menunjukkan bahwa ada hubungan kejadian ISPA dengan status gizi anak usia $2-5$ tahun $\left(x^{2}=12,377\right.$ dan $\left.p=0,002\right)$. Hal ini berarti bahwa status gizi dari anak yang menderita ISPA lebih buruk dari pada anak yang tidak menderita ISPA.

Tabel 11 Distribusi Sampel Berdasarkan Status Gizi dan ISPA

\begin{tabular}{cll} 
& \multicolumn{1}{c}{ ISPA } & Total \\
& $\begin{array}{l}\text { ISPA } \\
\text { Tidak }\end{array}$ & \\
Status & 12 & 30 \\
Gizi Baik & 18 & \\
Status Gizi & 11 & 16 \\
Kurang & 5 & \\
Status Gizi & 25 & 30 \\
Buruk & 5 & \\
Jumlah & $\mathbf{4 8}$ & $\mathbf{7 6}$ \\
& $\mathbf{2 8}$ & \\
\hline
\end{tabular}

\section{Hubungan Diare dengan Status Gizi}

Hasil Uji statistik Chi-Square menunjukkan bahwa tidak ada hubungan kejadian diare dengan status gizi anak usia $2-5$ tahun $\left(x^{2}=4,789\right.$ dan $\left.\mathrm{p}=0,091\right)$. Hal ini disebaabkan karena pada penelitian ini hanaya sedikit sekali sampel yang mengalami diare dalam 3 bulan terakhir $(1,3 \%)$.

\section{PEMBAHASAN}

\section{Karakteristik Pendidikan Ibu}

\section{Tingkat Pendidikan Ibu}

Dalam penelitian ini, tingkat pengetahuan ibu terendah 1 tahun, teringgi 13 tahun dan rata-rata 6,5 tahun dengan standar devisiasi 6,5 tahun. Sebagian besar responden tingkat pendidikannya kurang dari 9 tahun yaitu sebanyak $92 \%$ dan yang lebih dari 9 tahun ada $8 \%$. 
Hasil penelitian ini menunjukkan bahwa pendidikan responden rendah karena belum mencapai batas minimal pendidikan dara yang diwajibkan pemerintah yaitu sampai 9 tahun (Sisdiknas, 2002).

\section{Tingkat Pendapatan Per Kapita}

Tingkat pendapatan per kapita terendah Rp. 25.000,00 tertinggi Rp 200.000,00 dan rata-rata $\mathrm{Rp} 78.789,00$, dengan standar devisiasi Rp. 32.644,00. Sebagian besar responden tingkat pendapatan per kapitanya lebih besar dari 72.780,00/kapita/bulan yaitu sebanyak $57,9 \%$. Berdasarkan batas kemiskinan dari BPS yaitu Rp 72.780,00/kapita/bulan, sebagian besar responden tingkat pendapatannya diatas garis kemiskinan.

\section{Tingkat Pengetahuan Ibu Tentang Gizi}

Dalam penelitian ini, tingkat pengetahuan ibu tentang gizi terendah 5 , tertinggi 11 , dan rata-rata 9,2 dengan standar devisiasi 1,6 sebanyak 51,3\% responden tingkat pengetahuan gizinya termasuk kategori kurang.

Menurut Winarto (1990), pentingnya pengetahuan tentang gizi di dasarkan pada tiga kenyataan. Per1 41 status gizi yang cukup merupakan sesuatu yang penting bagi kesehatan. Kedua, seseorang akan cukup gizi jika makanan yang dimakan mampu menyediakan zat gizi yang diperlukan untuk pertumbuhan yang optimal, pemeliharaan, dan energy. Ketiga, ilmu gizi memberikan fakta-fakta yang perlu sehingga penduduk dapat belajar menggunakan pangan dengan baik bagi kesehatan.

\section{Jumlah Anggota Keluarga}

Dalam penelitian ini, jumlah anggota keluarga responden terendah 3 orang, tertinggi 12 orang, dan rata-rata 5 orang dengan standar devisiasi 1,6. Sebanyak $76,3 \%$ responden jumlah anggota keluarganya termasuk sedikit yaitu kurang dari 6 orang. Banyak sedikitnya anggota keluarga berhubungan dengan distribusi makanan dalam suatu keluarga. Hasil penelitian Dini Latief, dkk (2000) menunjukkan bahwa selama terjadi krisis moneter, distribusi pangan yang dikonsumsi semakin memberuk pada rumah tangga yang mempunyai anggota yang cukup besar.

\section{Tingkat Higiene Sanitasi Lingkungan}

Pada penelitian ini, skor hygiene sanitasi lingkungan responden terendah 10 , tertinggi 23 dan rata-rata 17 dengan standar devisiasi 17,12 sebanyak 52,6\% responden tingkat hygiene sanitasi lingkungannya termasuk dalam kategori cukup. Sanitasi lingkungan yang dinilai dalam penelitian ini meliputi ketersediaan air bersih, ketersediaan jamban, jneis lantai rumah serta kebersihan peralatan makan pada setiap keluarga.

\section{Hubungan Tingkat Pendidikan Ibu Dengan Tingkat Konsumsi Energi dan Protein}

Uji statistik Rank Spearman menunjukkan ada hubungan tingkat pendidikan ibu dengan tingkat konsumsi energy $(r=0,331$ dan $p=0,0003)$ dan tingkat konsumsi protein $(\mathrm{r}=0,383$ dan $\mathrm{p}$ $=0,0001$ ). Hal ini berarti bahwa semakin tinggi tingkat pendidikan ibu semakin tinggi tingkat konsumsi energi dan protein anaknya. Pendidikan sangat mempengaruhi penerimaan informasi termasuk informasi tentang gizi. Masyarakat dengan pendidikan yang rendah akan lebih mempertahankan tradisitradisi yang berhubungan dengan makanan sehingga sulit menerima informasi baru di bidang gizi (Suharjo,1992). Selain itu tingkat pendidikan juga ikut menentukan mudah tidaknya seseorang menerima suatu pengetahuan. Semakin tinggi tingkat pendidikan seseorang, aakn semakin mudah seseorang menyerap informasi yang diterima termasuk pendidikan dan informasi gizi terkait dengan pentingnya mengkonsumsi energy dan protein secara adekuat. Dengan pendidikan gizi tersebut 
diharapkan akan tercipta pola kebiasaan yang baik dan sehat (Handayani,1994).

\section{Hubungan Tingkat Pendapatan Perkapita Dengan Tingkat Konsumsi Energi dan Protein}

Uji statistik Rank Spearman menunjukkan tidak ada hubungan tingkat pendapatan per kapita dengan tingkat konsumsi energi $(r=0,100$ dan $p=0,389)$ dan protein $(\mathrm{r}=0,133$ dan $\mathrm{p}=0,251)$. Hal ini berarti tingkat konsumsi energy dan protein anatara anak dari keluarga miskin dengan anak yang berasal dari keluarga yang tidak miskin hamper sama. Hal ini terjadi karena masyarakat yang tingkat pendapatan per kapitanya dia tas garis kemiskinan tidak membelanjakan hartanya sesuai ilmu gizi. Kurangnya pengetahuan ibu tentang gizi berakibat pada rendahnya anggaran untuk belanja pangan dan mutu serat keanekaragaman makanan yang kurang. Keluarga lebih banyak membeli barang karena pengaruh kebiasaan, iklan dan lingkungan.

Penelitian dengan hasil yang sama dilakukan oleh Karjati dkk (1976) serta Fajans dkk ( 1983) yang tidak menemukan hubungan tingkat pendapatan dengan pertumbuhan balita. Hasil penelitian ini berbeda dengan pendapat Winarmo (1990) yang mengatakan jika tingkat pendapatan naik, jumlah dan jenis makanan juga akan membaik. Hasil penelitian ini berbeda dengan penelitian yang dilakukan oleh Alisyahbana (1984) yan menemukan bahwa ada hubungan pendapatan keluarga dengan keadaan gizi anak. Demikian juga penelitian yang dilakukan Satoto (1988) menunjukkan hubungan yang kuat kemakmuran keluarga dengan keadaan gizi.

\section{Hubungan Tingkat Pengetahuan Ibu Tentang Gizi Dengan Tingkat Konsumsi Energi dan Protein}

Hasil Uji statistik Rank
Spearman menunjukkan ada hubungan tingkat pengetahuan gizi ibu dengan tingkat konsumsi protein $(r=0,253$ dan $p$
$=0,027)$. Hal ini menunjukkan bahwa pengetahuan ibu tentang gizi mempunyai peranan dalam meningkatkan konsumsi protein. Hal ini sesuai dengan hasil penelitian yang dilakukan oleh Khumaidi (1994) yang menyebutkan bahwa pengetahuan ibu berpengaruh terhadap pola konsumsi makan keluarga sehingga dapat memperbaiki status gizi.

Pada penelitian ini, tidak ditemukan hubungan tingkat pengetahuan gizi ibu dengan tingkat konsumsi energy ( $r=0,222$ dan $p=0,142)$. Hal ini disebabkan karena mengkonsumsi makanan sumber utama energy merupakan sesuatu yang sudah umum berlaku dimasyarakat. Jadi, untuk mengkonsumsi makanan sumber energy masyarakat sudah tidak memerlukan pengetahuan khusus. Selain itu bias juga disebabkan karena bahan makanan sumber energy relative murah sehingga menjadi pilihan masyarakat pada saat terjadi krisis ekonomi sebagaimana hasil penelitian Latief dkk (1999) yang menunjukkan bahwa pada saat krisis ekonomi konsumsi bahan makanan sumber utama energi meningkat.

\section{Hubungan Jumlah Anggota Keluarga Dengan Tingkat Konsumsi Energi dan Protein}

Hasil Uji statistik Rank Spearman menunjukkan ada hubungan tingkat pengetahuan gizi ibu dengan tingkat konsumsi energi $(r=0,029$ dan $\mathrm{p}$ $=0,804)$ dan protein $(r=0,132$ dan $\mathrm{p}$ $=0,256$ ). Dalam penelitian ini, jumlah anggota keluarga responden rata-rata 5 orang. Menurut Dini Latief, dkk (2000) pada keluarga yang beranggotakan 3-5 orang rata-rata intake enrgi dan protein masih mendekatai nilai yang dianjurkan, sedangkan pada rumah tangga yang beranggotakan 6 orang atau lebih menunjukkan tingkat konsumsi pangan yang memburuk.

\section{Hubungan Tingkat Konsumsi Energi dan Protein Dengan Status Gizi}

Hasil Uji statistik Rank
Spearman menunjukkan bahwa ada 
hubungan konsumsi energy dengan status gizi anak usia 2-5 tahun $(r=0,328$ dan $p$ $=0,004$ ) demikian juga tingkat konsumsi protein dengan status gizi $(r=0,348$ dan $p$ $=0,002$ ). Hal ini berarti semakin tinggi tingkat konsumsi energi dan protein semakin baik status gizinya.

Bahwa masukan zat gizi terutama energy dan protein mempengaruhi keadaan gizi seseorang. Hal ini sesuai dengan pendapat Arnelia \& Sri Muljati (1991) yang mengatakan bahwa adanya penurunan status gizi disebabkan karena kurangnya jumalh makanan yang dikonsumsi baik secara kualittas maupun kuantitas. Menurut rumusan PERSAGI (Persatuan Ahli Gizi Indonesia) tentang penyebab gizi kurang, salah satu faktor yang mempengaruhi keadaan gizi adalah asupan makanan (Supariasa, 2012)

\section{Hubungan Tingkat Higiene Sanitasi Lingkungan Dengan ISPA}

Hasil Uji statistik Chi-Square menunjukkan bahwa tidak ada hubungan tingkat hygiene sanitasi lingkungan dengan terjadinya ISPA pada anak usia 2-5 tahun $\left(x^{2}=0,412\right.$ dan $\left.p=0,814\right)$. Hal ini berarti bahwa infeksi ISPA dapat terjadi pada tingkat hygiene sanitasi lingkungan baik, cukup, atau kurang.

Hasil penelitian ini berbeda dengan pendapat Pudjiadi (1990) yang mengatakan bahwa anak yang berada di lingkungan dengan keadaan hygiene yang buruk akan lebih mudah terserang infeksi. Chen (1983) mengatakan lingkungan sebagai sumber kontaminasi mikroorganisme yang menjurus pada kesakitan infeksi. Hal ini disebabkan karena data higiene sanitasi lingkungan kurang sensitif menggambarkan kondisi hygiene sanitasi lingkungan karena bentuk kuesionernya tertutup dan jawaban yang disediakan selalu, kadang-kadang, dan tidak pernah. Responden menjawab hanya berdasarkan memorinya saja.

\section{Hubungan Tingkat Higiene Sanitasi Lingkungan Dengan Diare}

Hasil Uji statistik Chi-Square menunjukkan bahwa tidak ada hubungan tingkat hygiene sanitasi lingkungan dengan terjadinya diare pada anak usia 2-5 tahun $\left(x^{2}=1,619\right.$ dan $\left.\mathrm{p}=0,445\right)$. Hal ini berarti bahwa penyakit diare dapat terjadi pada tingkat hygiene sanitasi lingkungan baik, cukup atau kurang. Hal ini disebabkan karena pada penelitian ini sangat sedikit sampel yang pernah mengalami diare. Hasil penelitian ini berbeda dengan pendapat Suharyono dkk (1998) yang menyebutkan bahwa keadaan hygiene sanitasi yang buruk merupakan salah satu penyebab diare secara tidak langsung.

\section{Hubungan ISPA dengan Status Gizi}

Hasil Uji statistik Chi-Square menunjukkan bahwa ada hubungan kejadian ISPA dengan status gizi anak usia 2-5 tahun $\left(x^{2}=12,377\right.$ dan $\left.p=0,002\right)$. Hal ini berarti bahwa status gizi dari anak yang menderita ISPA lebih buruk dari pada anak yang tidak menderita ISPA. Hal ini sesuai dengan pendapat Kabir (1994) yang mengatakan bahwa ISPA merupakan salahs atu penyakit infeksi yang mempengaruhi terjadinya gizi buruk. Menurut Winarmo (1990), infeksi dapat menurunkan nafsu makan atau menimbulkan kesulitan menelan dan mencerna makanan. Pada penderita ISPA biasanya nafsu makannya menurun, sehingga jumlah makanan yang seharusnya dikonsumsi tidak terpenuhi

\section{Hubungan Diare dengan Status Gizi}

Hasil Uji statistik Chi-Square menunjukkan bahwa tidak ada hubungan kejadian diare dengan status gizi anak usia 2-5 tahun $\left(x^{2}=4,789\right.$ dan $\left.\mathrm{p}=0,091\right)$. Hal ini disebaabkan karena pada penelitian ini hanaya sedikit sekali sampel yang mengalami diare dalam 3 bulan terakhir $(1,3 \%)$. Hasil penelitian ini berbeda dengan penelitian Scrimshaw (1981) yang mengemukakan bahwa dampak diare terhadap kedaan gizi dan pertumbuhan 
lebih dahsyat dari pada infeksi lain karena selama diare terjadi gangguan masukan, gangguan absorbsi, dan gangguan metabolisme secara bersamaan.

\section{KESIMPULAN}

1. Sebanyak 92\% responden tingkat pendidikannya rendah (kurang dari 9 tahun), 57,9\% responden tingkat pendapatannya di atas garis kemiskinan $51,3 \%$ responden tingkat pengetahuan gizinya termasuk dalam kategori kurang $76,3 \%$ responden jumlah anggota keluarganya sedikit ( $<6$ orang), dan $52,6 \%$ responden tingkat hygiene sanitasi lingkungannya termasuk kategori cukup.

2. Sebanyak 93,4\% sampel tingkat konsumsi energinya termasuk kategori defisit 35,5\% sampel tingkat konsumsi proteinnya termasuk kategori defisit. Selama 3 bulan terakhir 63,2\% sampel mengalami ISPA dan hanya 1,3\% sampel yang mengalami diare. Sampel yang mempunyai status gizi buruk sebanyak 39,6\%.

3. Ada hubungan tingkat pendidikan ibu dengan tingkat konsumsi energi $(\mathrm{p}=0,003)$ pada anak usia 2-5 tahun di Desa Tublopo Tahun 2014. Semakin tinggi pendidikan ibu semakin tinggi tingkat konsumsi energi anaknya.

4. Ada hubungan tingkat pendidikan ibu $(\mathrm{p}=0,001)$ dan tingkat pengetahuan ibu tentang gizi $(\mathrm{p}=0,027)$ dengan tingkat konsumsi protein pada anak usia 2-5 tahun di Desa Tublopo Tahun 2014. Semakin tinggi pendidikan ibu dan semakin baik pengetahuan ibu tentang gizi maka semakin tinggi tingkat konsumsi protein anakanya.

5. Ada hubungan tingkat konsumsi energi $(\mathrm{p}=0,004)$, tingkat konsumsi pr 51 $(\mathrm{p}=0,002)$ dan kejadian ISPA । 0,002 ) dengan status gizi pada anak usia 2-5 tahun di Desa Tublopo Tahun 2014. Semakin baik tingkat konsumsi energy dan protein maka semakin baik status gizi anak usia 2-5 tahun. Anak yang menderita ISPA status gizinya lebih buruk dari anak yang tidak menderita ISPA

6. Tidak ada hubungan tingkat pendapan per kapiita $(\mathrm{p}=0,389)$, tingkat pengetahuan ibu tentang gizi $(\mathrm{p}=0,222)$ dan jumlah anggota keluarga $(\mathrm{p}=0,804)$ dengan tingkat konsumsi energi pada anak usia 2-5 tahun di Desa Tublopo Tahun 2014.

7. Tidak ada hubungan tingkat pendapatan per kapita $(p=0,251)$ dan jumlah anggota keluarga $(\mathrm{p}=0,256)$ denagn tingkat konsumsi protein pada anak usia 2-5 tahun di Desa Tublopo Tahun 2014.

8. Tidak ada hubungan hygiene sanitasi lingkungan dengan kejadian ISPA $(\mathrm{p}=0,814)$ dan diare $(\mathrm{p}=0,445)$ pada anak usia 2-5 tahun di Desa Tublopo Tahun 2014.

9. Tidak ada hubungan kejadian diare $(\mathrm{p}=0,091)$ dengan status gizi pada anak usia 2-5 tahun di Desa Tublopo Tahun 2014.

\section{SARAN}

1. Bagi Masyarakat Mendorong masyarakat khususnya ibuibu yang belum memenuhi kewajibannya wajib belajar 9 tahun untuk mengikuti program paket $\mathrm{C}$

2. Bagi Dinas Kesehatan Kabupaten TTU Membuat penyuluhan yang menarik untuk meningkatkan pengetahuan ibu tentang giiz dan pentingnya pencegahan ISPA

3. Bagi Peneliti

Melanjutkan kembali penelitian tersebut dan jika memungkinkan untuk memberi intervensi untuk masyarakat setempat.

\section{DAFTAR PUSTAKA}

Alamatsier, Suniata. 2001. Prinsip Dasar Ilmu Gizi. PT. Gramedia Pustaka Utama, Jakarta

Arisman, MB. 2004. Gizi Dalam Daur Kehidupan. EGC.Jakarta, 
Aritonang, I. 2002. Krisis Ekonomi. Akar

Masalah Gizi, Sebelas Maret

University Press, Surakarta.

Arnelia, dan S Muljati. 1991. Status Gizi Anak Balita Pengunjung Posyandu Kecamatan Ciomas dan Samplak. Kabupaten Bogor.

Basuni, A.J, dkk. 2000. Status Gizi Anak Balita di Indonesia Sebelum dan Selama Krisis (Analisis Data Antropometri Susenas 1989 s/d 1999). Widya Karya Nasional Pangan dan Gizi.

Berg, A. 1986. Peranan Gizi Dalam Pembangunan Nasional. Rajawali: Jakarta

Budiarti,E. 2002. Biostatistik untuk Kedokteran dan kesehatan Masyarakat. EGC : Jakarta

Dep. Kes RI. 2002. Pemantauan Pertumbuhan Balita

Direktorat gizi

DepertemenKesehatanRI: Jakarta

Dini, Latief,dkk. 2000. Konsumsi Pangan Tingkat rumah Tangga Sebelum dan Selama Krisis Ekonomi, Makalah disampaikan pada Widya Karya Nasional Pangan dan Gizi VII. Jakarta

Dini, Latief,dkk. 2000. Program ASI Eksklusif dan Makanan Pendamping ASI, Kumpulan Makalah, Diskusi Pakar Bidang Gizi

Dinkes. 2001. Profil Kesehatan Propinsi Nusa Tenggara Timur

Djaelani, A, S. 1989. Ilmu Gizi untuk Mahasiswa dan Profesi Jilid 2. Dian Rakyat : Jakarta

Ezzel, I and L Jensen. G. $198 \quad 54$ Malnutrition in Chronic Obstructive Pulmonary Disease. American Jurnal Clinical Nutrition.

Fatimah, SM. 2001. Keadaan Gizi Kelompok Rawan Tinjauan Sebelum dan Selama Masa
Krisis, Pidato Pengukuhan Jabatan Guru Besar Madya dalam Ilmu Gizi . Fakultas Kedokteran Universitas Diponegoro. Badan Penerbit Universitas Diponegoro, Semarang

Handayani, Sri. 1994. Pangan dan Gizi. Sebelas Maret University Press. Surakarta.

Jusat , I dan Janari, AB. 2000. Review Antropometri Secara Nasional dan Internasional, Kumpulan Makalahh, Diskusi Pakar Bidang Gizi.

Kabir, I, dkk. 1994. Changes in Body Composition of Malnourished Children after Dietary Supplementation as measured by Bioelectrical impedance, American Jurnal Clinical Nutrition

Khumaidi, dkk. 1994. Gizi Masyarakat. PT BPK Gunung Mulia : Jakarta.

Kurniawan, dkk. 2001. Childhood Malnutrition in Indonesia, in Current Situation

Lamesshow, dkk. 1997. Besar Sampel dalam Penelitian Kesehatan. Gajahmada : University Press : Yogyakarta.

Muhilal, dkk. 1998. Angka Kecukupan Gizi yang Dianjurkan. Makalah disampaikan pada Widyakarya Nasional Pangan dan Gizi VI, LIPI : Jakarta.

Notoatmojo, S. 2002. Metodologi Penelitian Kesehatan. Rineka Cipta: Jakarta

Oakley, dkk. 1997. Effect of Diet Quality and Sosioeconomic Characteristic, on Body Mass Index of Children, American Jurnal Clinical Nutrition

Parsudi. 2006. Hubungan Karakteristik Ibu Dengan Status Gizi Balita di Desa Kedalingan Kecamatan Tambakromo Kabupaten Pati. Skripsi : STIKes Cendekia 
Utama, Kudus, Tidak dipublikasikan

Poedjiadi A. 1994. Dasar-Dasar Biokimia. Universitas Indonesia Press : Jakarta

Priyanti, ZS. 1996. Diagnosa dan Penatalaksanaan Pneumonia, EGC : Jakarta

Pudjiadi, S. 1990. Ilmu Gizi Klinis Pada Anak. Fakultas Kedokteran : Universitas Indonesia, Jakarta

Raharto, dkk. 2000. Identifikasi Rumah Tangga Miskin. Makalah disampaikan paad Widya Karya Nasional Pangan dan Gizi : Jakarta

Ratmono, T. 2006. Hubungan Pengetahuan, Sikap dan Perilaku Ibu Balita dalam Pemanfaatna Posyandu dengan Status Gizi Balita di Dusun Bongorejo Desa Bongorejo Kecamtan Japal Kabupaten Blora. Skripsi : STIKes Cendekia Utama, Kudus, Tidak Dipublikasikan

Rifai, M.A. 2004. Pegengan Gaya Penulisan, Penyuntingan, dan Penerbitan, Karya Ilmiah Indonesia, Gadjah Mada University Press, Yogyakarta,

Roggero, dkk. 1997. Factor Influencing Malnutrion In Children Waiting For Liver Transplants, American Jurnal Clinical Nutrition.

Santosa. 2006. Hubungan Antara Pengetahuan, Sikap, dan Praktek Ibu Dalam Pemberian Makanan Bergizi Dengan Status Gizi Balita di Desa Mulyoharjo Kec. Pati Kabupaten Pati. Skripsi : STIKes Cendekia Utama, Kudus, Tidak dipublikasikan

Santoso , S. 2003. Mengatasi Berbagai Masalah Statistik dengan SPSS Versi ii, 5, Elex Media Komputer : Jakarta
Sastroasmoro, dkk. 1995. Dasar-Dasar Metodologi Penelitian Klinis, Bina Rupa Akasara : Jakarta

Satoto. 1990. Pertumbuhan dan Perkembangan Anak, Pengamatan Anak umur 0-18 bulan di Kecamatan Mioggo, Kabupaten Jepara Jawa Tengah, Disertasi Doktor

Sayogjo. 1978. Menuju Gizi Baik yang Merata di Pedesaan dan Perkotaan. Gajah Madah University : Yogyakarta

Soekirman. 2000. Ilmu Gizi dan Aplikasinya untuk Keluarga dan Masyarakat, Direktorat Jenderal Pendidikan Tinggi Departemen Pendidikan Nasional.

Soendjojo, dkk. 2000. Menstimulasi Anak Usia 0-1 tahun. PT. Elexmedia Komputindo : Jakarta

Suandi. 1998. Diit Pada Saat Anank Sakit. EGC : Jakarta

Sugiyono. 2002. Statistik Untuk Penelitian. CV : Alfa Beta Bandung

Suhardjo. 1996. Peranan Pangan dan Gizi : Bumi Aksara

Suharjo. 1992. Pemberian Makanan Pada Bayi dan Anak Kanisius, Yogyakarta

Suharyono, dkk. 1998. Gantroenterologi Anak Praktis. FKUI : Jakarta

Sulistiyorini, D. 2006. Hubungan Pengetahuan, Sikap dan Praktek Gizi Ibu dengan Status Gizi Balita di Wilayah Kerja Puskesmas Gabus I Kabupaten Pati. Skripsi : STIKes : Cendekia Utama, Kudus, Tidak dipublikasikan

Supariasa, dkk. 2002. Penilaian Status Gizi. Penerbit Buku Kedokteran EGC : Jakarta

Tabor, dkk. 2000. Keterkaitan anatar Krisis Ekonomi, Ketahanan Pangan dan Perbaikan, Makalah disampaikan pada 
Widya Karya Pangan Nasional

Pangan dan Gizi VII, Jakarta

Undang-undang RI No. 20 Tahun 2003

Tentang Sistem Pendidikan

Nasional. Depertemen

Pendidikan Nasional RI,

Jakarta

Widajanti, dkk. 1999. Perubahan

Konsumsi Pangan dan
TINGKAT Kecukupan Gizi Anak Sekolah Dasar di Kodia Semarang pada Masa Krisis Moneter Tahun 1997/1998. Lembaga penelitian UNDIP : Semarang

Winarmo, FG. 1990. Gizi dan Masyarakat bagi Bayi dan Anak Sapihan. Pustaka Sinar Harapan : Jakarta 